PNL-3439 ES

UC-11

Exec. Sum.

Executive Summary

\title{
Some Implications of In Situ Uranium Mining Technology Development
}
C. E. Cowan
D. Keller
M. A. Parkhurst
P. J. Mellinger
R. J. Cole
R. W. Wallace

September 1980

Prepared for

the U.S. Department of Energy

Assistant Secretary for Environment

Office of Environment Assessments

under Contract DE-AC06-76RLO 1830

Pacific Northwest Laboratory

Operated for the U.S. Department of Energy

by Battelle Memorial Institute 
NOTICE

This report was prepared as an account of work sponsored by the United States Government. Neither the United States nor the Department of Energy, nor any of their employees, nor any of their contractors, subcontractors, or their employees, makes any warranty, express or implied, or assumes any legal liability or responsibility for the accuracy, completeness or usefulness of any information, apparatus, product or process disclosed, or represents that its use would not infringe privately owned rights.

The views, opinions and conclusions contained in this report are those of the contractor and do not necessarily represent those of the United States Government or the United States Department of Energy.

\author{
PACIFIC NORTHWEST LABORATORY \\ operated by \\ BATTELLE \\ for the \\ UNITED STATES DEPARTMENT OF ENERGY \\ Under Contract EY-76-C-06-1830
}
Printed in the United States of America Available from
National Technical Information Service
United States Department of Commerce
5285 Port Royal Road
Springfield, Virginia 22151

Price: Printed Copy $\mathbf{s}$

$\approx$ Microfiche $\$ 3.00$

$\begin{array}{cc}\text { *Pages } & \text { NTIS } \\ & \text { Selling Price } \\ 001-025 & \$ 4.00 \\ 026-050 & \$ 4.50 \\ 051-075 & \$ 5.25 \\ 076-100 & \$ 6.00 \\ 101-125 & \$ 6.50 \\ 126-150 & \$ 7.25 \\ 151-175 & \$ 8.00 \\ 176-200 & \$ 9.00 \\ 201-225 & \$ 9.25 \\ 226-250 & \$ 9.50 \\ 251-275 & \$ 10.75 \\ 276-300 & \$ 11.00\end{array}$


SOME IMPLICATIONS OF IN SITU URANIUM MINING TECHNOLOGY DEVELOPMENT

Prepared by

C. E. Cowan

M. A. Parkhurst

R. J. Cole

D. Keller

P. J. Mellinger

R. W. Wallace

September 1980

Prepared for

the U.S. Department of Energy Assistant Secretary for Environment

Office of Environment Assessments under Contract DE-AC06-76RLO 1830

W. N. Thomasson, Project Monitor Technology Assessments Division

Pacific Northwest Laboratory

Richland, Washington 99352 


\section{CONTENTS}

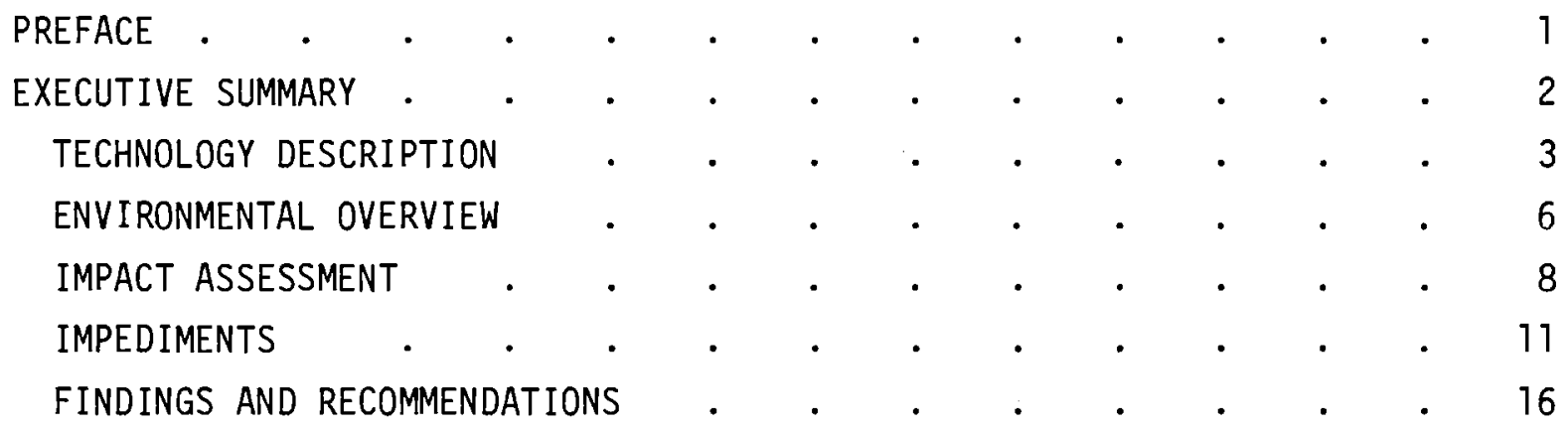




\section{PREFACE}

Some Implications of In Situ Uranium Mining Technology Development is a detailed report that was prepared for the Technology Assessments Division Office of Environmental Assessments under Assistant Secretary of the Environment in the United States Department of Energy (DOE). It has been distributed to regulatory, industry and interest group representatives. The report will be used as a source document for the DOE's Technology Assessment of In Situ Uranium Mining.

This is the executive summary of that report and includes sufficient information for a reader to gain an understanding of this new technology and the major findings of the study. The full report is available through the National Technical Information Service, 5285 Port Royal Road, Springfield, Virginia 22151. 


\section{EXECUTIVE SUMMARY}

In recent years, in situ mining of uranium has emerged as a viable method for recovery of uranium from sandstone ore bodies. Since the licensing of the first commercial facility in 1975 in Texas, the industry has grown to 17 commercial operations and numerous pilot facilities in four states. Because of the technology's low capital and operational costs, persons familiar with the technology expect to see even more growth in numbers of commercial facilities and in geographic locations in the next few years. There are predictions that in situ mining will account for over $10 \%$ of the United States production of yellowcake in the near future. In those areas where in situ mining technology is applicable, it is receiving considerable attention by industry, regulators and public interest groups. According to Buma, * in situ uranium mining technology has increased the minable uranium ore reserves by three times, although this increase has not been confirmed by the USDOE estimates.

Based on the need to develop environmentally acceptable methods for energy production, including ore extraction, and the need to be cognizant of potential environmental impacts of new or expanding technologies, the Technology Assessments Division of the Office of Environmental Assessments under the Assistant Secretary for Environment in the United States Department of Energy (USDOE) initiated a technology assessment of the in situ uranium mining technology in March 1979. Various aspects of this technology assessment are being conducted by Battelle at the Pacific Northwest Laboratory and at Battelle's Human Affairs Research Center and by the Futures Group, Inc., under the direction of the USDOE. The Technology Assessment is scheduled for completion in 1981. While the technology assessment is primarily orientated toward the Office of Environment in the USDOE and concerns of primary interest to that agency, many parts of the technology assessment will be of interest to other Federal agencies, state governments, industrial firms and public interest groups.

The primary focus of the study by the Battelle research staff, which is reported here, was to explore the impediments to development and deployment of the in situ uranium mining technology and to evaluate the environmental impacts of a generic in situ facility. This report is intended to be a source document for the technology assessment.

Background information is derived from current operations in Texas and Wyoming. The data and information came from the open literature and from

* Buma, G. 1977. Uranium solution mining state-of-the-art. Contributed by the Petroleum Division of the American Society of Mechanical Engineers for presentation at the Energy Technology Conference and Exhibit, Houston, Texas, September 18-22, 1977. The American Society of Mechanical Engineers. New York. 
discussions with Federal, state and local officials, public interest groups and industry representatives, from license dockets, and from a workshop conducted by Battelle staff.

In order to identify and evaluate the impacts and impediments, the first step is to describe the technology and the environment in which the technology exists. Thus, the first three chapters of the report describe the current technology, physical and ecological environment and the institutional and socioeconomic environment. Based on this description of the technology and its environmental setting, the potential impacts are identified and evaluated. Additionally, potential issues or problems that could impede development and deployment of the technology are identified and discussed. Both impacts and impediments are presented because even if the technology has acceptable or positive impacts on the physical, ecological, institutional and social environments, the impediments could still prevent or hinder the development and application of the technology.

The study reported here indicates that, based on available information, there do not appear to be any significant demonstrated negative environmental impacts. Moreover, the impacts of in situ mining compare favorably with those impacts expected from conventional mining techniques. Exposure to radioactive elements is less, atmospheric emissions of radioactive and nonradioactive materials are generally less and socioeconomic impacts are decreased. In fact, because of the generally small and unskilled labor forces associated with in situ mining, development has provided much needed economic stimulus to economically depressed areas of Texas. There are still, however, several areas of unknowns and several areas of inadequate information that will need to be addressed before a complete quantification evaluation of impacts can be made. These areas include, but are not limited to, levels of radon emissions and groundwater restoration methods and impacts. Several issues mostly relating to the interaction of industry with state and Federal regulators need to be addressed. Currently, research and monitoring programs are underway to evaluate the unknowns and increased emphasis is being placed on clearer and more frequent communications between regulators and industry representatives in efforts to address the impediments and impacts in a responsible manner.

The remainder of this summary contains brief overviews of each of the report chapters. More details on any of the aspects covered in the summary are found in the report.

\section{TECHNOLOGY DESCRIPTION}

The first step in developing an in situ uranium mining facility is to locate an ore body with sufficient uranium for economic mining. Techniques for locating and assaying uranium ore bodies are the same for in situ mining as for conventional mining methods. However, in addition to being an economically minable body, the ore body must meet several geologic criteria. These criteria are: 
- complete saturation with groundwater

- permeability, porosity and hydrology that are favorable for application of the technology

- uranium form that is amenable to leaching.

Generally, a relatively horizontal bed underlain and overlain by impermeable strata is required; however, these impermeable strata above or below the ore body may not be necessary if vertical permeability is low and the other geologic criteria are met.

Once the ore body has been defined and shown to be amenable to in situ leaching, the in situ facility is constructed. The two parts of the in situ facility are the well field and the main processing facility where the uranium is recovered. In situ facilities range in size from research and development or pilot facilities which produce less than 100,000 lbs $(45,360 \mathrm{~kg})$ of yellowcake during the duration of facility operation to large commercial facilities which produce up to $2,000,000$ ibs $(907,200 \mathrm{~kg})$ of yellowcake per year. The well fields are constructed in patterns that are chosen to maximize hydraulic and economic factors determined by the characteristics of the ore body. Usually the well field design is based on one of several common patterns with the distances between the wells determined by the geohydrology and geochemistry of the site. Each well is constructed to meet regulatory requirements and to prevent movement of fluid into potable aquifers. A well field can occupy from a few acres to a few hundred acres of 1 and.

The central processing plant, which usually occupies only a few acres of land, contains processing tanks, chemical storage tanks and, when the final product is dried yellowcake instead of yellowcake slurry, may contain a dryer facility. In the southern, warmer and drier areas, the process tanks are commonly placed on a cement slab with little or no cover, whereas in the north, all processing equipment is kept inside to prevent freezing.

The uranium recovery process consists of two main circuits within which fluids are recycled. The first circuit is called the lixiviant sorption circuit and consists of injection of lixiviant into the ore body, extraction of the uranium by the lixiviant solution and sorption of the uranium in the solution onto an ion exchange column. The two types of lixiviant solutions which have been used to extract the uranium are alkaline and acid lixiviants. Ammonium carbonate-bicarbonate lixiviant, a type of alkaline lixiviant, is used most frequently because of its compatibility with the geochemistry of the ore bodies currently being mined. The second circuit is called the elution/ precipitation circuit, which consists of the elution of uranium from the ion exchange column by a salt solution and precipitation from solution by addition of appropriate chemicals. This precipitated uranium solution, called yellowcake slurry, may be shipped directly to the uranium hexafluoride plant or dried to a powder, yellowcake, and packed in drums before shipping. 
Since most of the fluids used in the uranium recovery process are recycled, there is very little liquid waste. The primary source of liquid wastes are $1-2 \%$ bleeds of the lixiviant and eluant streams to prevent buildup of contaminants. Other liquid waste streams include filter backwashes and scrubber system effluents. Solid wastes which are small in overall volume, consist primarily of contaminated sand in Texas and calcite sludges in Wyoming. There are also some small amounts of atmospheric emissions from release of process chemicals, evaporation from ponds, and dryer emissions. Liquid wastes are placed in lined evaporation ponds, either for evaporative volume reduction or as a holding pond before deep well injection. The small amounts of solid waste are drummed and sent to a licensed low-level burial site.

Before, during, and after operation of an in situ facility, information is gathered about the environment, potential discharges and potential environmental impacts on a regular and specified basis. These monitoring programs include surveys of the air, water, soils, plants and animals for the effects of both radiological and nonradiological effluents. There are inplant programs that monitor workers for radiological and chemical exposures, including exposure to uranium compounds. The purpose of the monitoring programs is to detect any significant change in the various parameters and allow for early mitigation before a significant impact can take place.

The monitoring of the groundwater outside the mine zone is important for detection of excursions of the lixiviant solution. An elevation of the concentration of specified groundwater constituents indicates an excursion and corrective operations can be initiated. The excursion can be corrected by overproduction, modifying the injection/production balance of the well field, or by reducing or stopping injection.

After mining of the ore body has been completed, the groundwater must be restored to a specified level of constituent concentrations. The most direct and widely considered technique is pumping the residual fluids from the well field. As pumping continues, the fluid in the ore body is replaced by groundwater from outside the well field. Pumping continues until the groundwater quality is restored to premining levels. This method, called groundwater sweeping, is very simple and effective but is highly water consumptive and results in large volumes of waste water that must be placed in the lined evaporation ponds and disposed of as other liquid wastes. 0ther methods that have been suggested include recirculation or clean water recycle, injection of specifically tailored fluids to aid in recovery of hard-to-remove elements or to stabilize elements. Bacterial and chemical precipitation techniques are being researched.

After all mining and restoration are completed, the buildings are decontaminated and removed. The ponds are emptied of wastes and leveled. Finally, at the discretion of the landowner, the site is revegetated with native vegetation. 


\section{ENVIRONMENTAL OVERVIEW}

Uranium sandstone deposits are believed to have formed when the uranium was leached from a source material, probably granite ore bodies, and transported in a dissolved state by the groundwater. oxygenated groundwater percolating through the source material oxidized and mobilized the uranium. As the uranium bearing groundwater moved through the aquifer, it came in contact with reducing conditions. The uranium precipitated out along the oxidation-reduction front in what is commonly referred to as the roll-type mineralized deposit.

The uranium sandstone deposits are found throughout the western United States from Washington to Texas. Because of the wide range of geological locations of deposits there is a great variation in the physical and ecological environment from areas of low rainfall (less than $8.8 \mathrm{~cm}$ ) to areas with a large rainfall $(51.6 \mathrm{~cm})$. Likewise there is a wide range in vegetation community types and land uses. Generally, however, most in situ facilities are located in areas remote from large population centers and in areas of sparse vegetation (fields, pastures or rangeland). Surface hydrology consists primarily of ephemeral streams or tributaries with low flow rates. Some surface waters contain high amounts of vanadium and moderate amounts of other trace metals. Groundwater occurs in thick sedentary sequences throughout the region. The groundwater commonly contains trace and heavy metals although concentrations are usually within acceptable public health limits.

Radioactive element concentrations may, however, be above standards in wells near ore bodies.

The institutional and socioeconomic environments surrounding in situ mining in Texas and Wyoming are considered for the five stages: exploration and testing, mine construction, mine operation, waste disposal, and reclamation. At each stage, the economic participants and activities, governmental participants and activities, and public interest group participants and activities may vary. One set of the participants remains involved throughout all the stages, and others are added at later stages, but once added, remain through the final stage.

The principal economic participants are either subsidiaries of large corporations or small independent operators. The subsidiaries generally belong to energy companies, al though one of them is owned by U.S. Steel corporation. The product is in demand; most of the supplies needed for production are readily available. The labor needed is generally unskilled and nonunionized; equipment -- principally water well drilling rigs -- is also available. 0il drilling rigs may not be available for mining deeper ore bodies which could constrain development of some deposits. The shortage of engineers and geologists skilled in in situ mining techniques could constrain development.

In both Texas and Wyoming, Federal, state, and local agencies are actively involved in licensing in situ facilities. Texas is an agreement 
state, * therefore the USNRC is less directly involved in licensing in situ facilities than in Wyoming, a nonagreement state. The USEPA is also involved, primarily through promulgating regulations that state agencies must enforce. State agencies also impose their own regulations on the industry and local agencies have jurisdiction over roads and utilities.

Most of the governmental activity has been direct regulation of the industry. No level of government, to our knowledge, has been involved in any major support activities. The areas regulated include pollution control, occupational safety, and nuclear safety and safeguards. Concerns over use of water and its purity may result in additional regulations being developed.

Local governments, in addition to regulating the industry, have had to deal with some of its impacts. Industrial development has led to marked growth in population in certain areas, with consequent need for government services. However, in every case so far, in situ mining has been but a small addition to an already large impact from other forms of uranium production and other energy source development. One positive aspect of in situ technology development is that it allows mining of uranium to occur with a reduction in overall impacts compared to the use of conventional mining and milling techniques.

A potential new participant that has both governmental and economic interests is Indian tribes. In some areas of the country, they own large reserves of uranium that could be exploited by in situ mining techniques. Therefore, they would be owners and regulators of the resource. The development of tribal reserves would involve the Bureau of Indian Affairs as another Federal governmental participant.

Public interest group participants and activities are the same for all five stages. In general, the interest groups are either environmental groups or local residents. Environmental groups have shown mixed feelings about the in situ technology. Some environmental groups see the technology as offering a great promise for a less environmentally damaging way to exploit uranium resources. However, there is some concern that improper application of such techniques could lower groundwater quality.

Local residents generally have somewhat similar mixed feelings. The minimal visual and environmental impacts of in situ facilities make them much more attractive neighbors than open pit or underground mining. In addition,

* An Agreement State is any state which has entered into an agreement with the United States Nuclear Regulatory Commission under provisions of the Atomic Energy Act of 1954. The state then has the authority to regulate any one or more of the following materials: byproduct, source material or special nuclear material in quantities not sufficient to form a critical mass, for protection of public health and safety from radiological hazards. 
they provide a new source of employment for area residents. At the same time, they make resource exploitation feasible in areas that would not have been touched without the techniques and so may upset those who want an absolutely pristine environment.

\section{IMPACT ASSESSMENT}

In situ uranium mining has been hailed as an environmentally safe method for extraction of uranium by some advocates and recommended as an environmentally desirable alternative to conventional uranium mining methods. Based on available information, our evaluation shows that in situ uranium mining operations do not adversely affect the physical, chemical, ecological, social or institutional environments as much as conventional uranium mining methods do. The rural communities experience economic stimulation that does not stress local institutions in the way in which other technologies often do with the boom/bust cycle. However, there are several areas where more data is needed before a complete evaluation can be made.

Generally, construction activities account for the greatest nonradiological impact on air quality through fugitive dust and diesel emissions. Routine operations result in only minor releases to the atmosphere of nonradiological constituents from process emissions, chemical storage tank vents and waste storage ponds. Radiological releases from the same sources are also small. The greatest source of measured radiological emissions is the dryer stack which is equipped with a Venturi scrubber. In five years of in situ facility operations in Texas, no radioactive releases have been measured at the fence line above standards of 10 CFR 20, Table II (Pers. Com. to C. E. Cowan from E. D. Bailey, Texas Department of Health, May 29, 1979). The level of radon emissions especially in the workplace is unknown at this time, although they are believed to be less than for a comparable conventional uranium mining and milling operation.

During routine operations, in situ facilities do not discharge waste waters into surface waters; therefore, contamination of surface waters should not occur. Although there is a possibility that surface waters could be contaminated by migration of contaminated groundwater, the probability is believed to be remote due to the existence of systems for monitoring for excursions, techniques and requirements for restoration, and geochemical processes which are believed to limit migration of contaminants.

Groundwater contamination from mining is unlikely because of excursion monitoring, restoration and natural geochemical processes. Seepage of waste water from ponds is also unlikely because of the use of lined ponds and leak detection systems. However, there are potential adverse impacts on the groundwater due to withdrawal of water during mining and especially during restoration. Continuous withdrawal of water during mining could affect other local users through lowering of water levels and depletion of water resources. Restoration withdrawals are large enough to seriously impact neighboring water supplies and could influence groundwater flow patterns and quantity of flow for considerable distances. 
Due to the very small amount of surface area disturbed during construction and operation, loss of flora and fauna will be minor. There will also be some minor impacts on fauna due to noise and traffic. Effects of effluents on flora and fauna are judged to be minor based on past experience.

In situ uranium mining is a safe industry for occupational workers. Although no documented information was available, many plant operators stated that occupational exposure to chemicals is kept well below regulations. Radiological exposure is very low. In fact, in eight years of operation, no incident involving occupational exposure has occurred which has resulted in restricting workers activities or working hours.* Likewise, public exposure to either radiological or nonradiological chemicals is even lower and has never been above standards (10 CFR 20) or resulted in restrictions on the in situ uranium mining facility.

As the technology spreads into new regions or experiences rapid growth in areas where it already exists, impacts on the institutional and socioeconomic environment are likely to occur. Institutional impacts include legal impacts, organizational impacts and political impacts. Socioeconomic impacts include business impacts, fiscal impacts, psychological impacts, and sociological impacts. All of these impacts, expected to occur from any single in situ mining facility, are likely to be far smaller than those arising from more conventional uranium mining techniques. However, since in situ mining techniques allow operations on a smaller scale, more areas may be affected and multiple facilities may occur in a given uranium-bearing area.

Legal impacts can include legislation or litigation aimed at settling legal issues arising from the mining technology or its effects. Experience in Texas and Wyoming suggests the following impacts are possible:

- New interpretations of existing laws may be needed.

- New laws that exempt or specifically address in situ mining techniques may be required.

- Legislation to assign agency jurisdiction over new activities may be required.

- The question of regulation on Indian Lands may need to be resolved.

Organizational impacts include changes in the existence or operation of organizations. The principal impact of this type associated with in situ mining is to require the creation of a new agency or the modification of an existing one to regulate it. The regulations, expertise, and resources of the

* Hunkin, G. G. 1979. Uranium in-situ mining: a report to the Roya 1 Commission of Inquiry concerning the health and environmental protection uranium mining. Hunkin Engineers, Inc., Littleton, Colorado. 
existing agencies may not be appropriate to this new mining technique. Until responsibilities are clearly assigned, organizations may overlap in jurisdiction. For instance, it took an interagency memorandum to resolve whether the Occupational Safety and Health Administration (OSHA) or the Mine Safety and Health Administration (MSHA) should protect the workers at in situ facilities who are now governed by MSHA.

Political impacts include the use of the political process to express opinions about the technology or its effects. Some of the following impacts are possible:

- Opposition to in situ mining based on threats to groundwater could arise.

- In situ techniques could provide a new focus for those who oppose nuclear power generally.

- The spread of nuclear activities to new areas made economically feasible by in situ techniques may create controversies in states that have not had such controversies before.

- The influx of newcomers into usually remote areas is apt to have effects on the political activities of local communities. likely:

Business impacts are effects on business operations. The following are

- Competition for labor and equipment, especially skilled engineers and more powerful drilling rigs.

- Increased competition for unskilled workers between in situ mining facilities and local businesses.

Fiscal impacts include effects on governments resulting from efforts to provide basic services and raise revenues by which to do so. The following are possible:

- Local governments may experience strains if they are asked to provide basic services to an increasing population.

- Local governments may have to provide new services as well as expanded levels of old ones.

- In situ facilities, because of their capital intensity (cost for capital exceeds cost for labor), may provide more revenue per impact (e.g., school, police) than would other facilities. 
Psychological impacts include changes in perceptions, attitudes, beliefs, and behavior. The following are possible:

- Landowners may be more willing to allow in situ mining on their land than mining that disrupts the 1 andscape.

- In situ techniques may make uranium mining activities more acceptable because in situ activities are less visible.

- Increased in situ activities could create worry and may create opposition among those who were previously untouched by any form of nuclear activity.

Sociological impacts include effects on the structure or nature of communities, social institutions, and lifestyles. Experience in Texas and Wyoming suggest the following:

- Radical changes in lifestyles or sociological patterns are not anticipated from any one in situ facility.

- Economic changes resulting from in situ operations may slow down or reverse other sociological changes that may have otherwise occurred, such as large-scale migration to urban areas in search of higher paying jobs.

\section{IMPEDIMENTS}

It is important to be aware of not only the potential environmental impacts of the in situ uranium mining technology but also of any problems or issues that may act to varying degrees as constraints or impediments to the development and deployment of the technology. The list of issues and explanatory information given below was developed from the literature, informal interviews with regulatory and interest group representatives and data collected at a workship held in Corpus Christi, Texas in November 1979.* These issues have been categorized into major, minor and latent issues in the report based on the extent to which they constrain or impede the technology. In this summary the major issues are emphasized.

The major environmental health and safety issues are concerned primarily with various aspects of groundwater restoration. These issues inciude consumptive use of groundwater, nitrate-nitrite formation in groundwater due to use of ammonia lixiviants, ammonia/nitrate persistence during restoration, acceptable/reasonable standards for groundwater restoration limits and for evaluation of restoration capacity. The major institutional and socioeconomic

* Cowan, C. E., and M. A. Parkhurst. 1980. Proceedings of Workshop on In-Situ Uranium Mining Technology. November 28-30, 1979, Corpus Christi, TX. CONF-791191. TIC, Oak Ridge, TN. 
issues are concerned primarily with the interactions between government regulators and industry. These issues include uncertainties about standards and criteria, understanding and knowledge of in situ technology, exchange of technical and other related information, current enforcement practices, and acceptable restoration goals.

At present the exact restoration goals are not clearly defined and regulations vary significantly from agency to agency. Restoration is defined as the reduction of the quantity of dissolved minerals within the mined ore aquifer to levels that protect the environment and human health; however, there is considerable debate as to what levels are acceptable or what is necessary to protect public health and safety. Several of the possibilities discussed include:

- Restoration to baseline water quality values.

- Restoration of constituents to a given amount or percentage above baseline.

- Restoration to values consistent with defined water use category.

- Restoration to better than previous use classification if the previous use classification was due to the presence of the mined element.

- Restoration to within established water quality standards.

Restoration of the groundwater back to baseline is generally considered to be the most difficult to achieve and may be technically impossible because of physical-chemical changes in the geochemical formation resulting from uranium extraction and lixiviant ion exchange on the clays. Restoration to other levels, such as previous water use category is much less difficult technically but depends on the type of lixiviant solution used, confinement of the aquifer and other site specific parameters. Therefore, the feasibility of successful restoration depends to a great extent on the levels which are chosen as restoration standards. Very stringent restoration goals may make restoration infeasible either technically or economically and impede further development of the technology. However, adequate protection of the public needs to be assured.

The most commonly employed method of groundwater restoration is groundwater sweeping. This involves removal of groundwater from the mined zone with resulting inflow and dilution by freshwater pulled into the mine zone until the restoration goals are reached. This method is highly water consumptive and can severely impact groundwater supplies in arid areas where uranium mining occurs. Thus, a need exists to develop less water consumptive methods in order to reduce the impact of restoration on groundwater supplies. Reverse osmosis units, which remove contaminants and allow reinjection of much of the waste water, have been suggested as an alternative to groundwater sweeping; however, these units have been unreliable under field conditions. Development and demonstration of practical and economical methods for reducing the groundwater 
depletion impact during restoration may be necessary before the technology can become viable in many arid areas of the country.

Currently, most in situ uranium mining operations use ammonia bicarbonate-carbonate leach solutions. However, there is a great deal of concern about the potential environmental and public health impacts of ammonia that could be converted to nitrates and nitrites. Some levels of nitrates and nitrites are acceptable in the groundwater to meet standards for the protection of public health. Nevertheless, because of these public health and environmental concerns, leach systems that do not use armonia need to be developed and demonstrated. Non-ammonia leach systems that use sodium bicarbonate or sulfuric acid are also known to result in some environmental impacts and restoration problems; therefore, other systems may need to be developed and demonstrated to be technically effective and environmentally safe. The ideal lixiviant would be one that would oxidize the uranium, maintain it in solution by complexation and interact little with the barren host rock. No lixiviant tested to date is entirely inert to other minerals associated with the uranium.

A related concern is the restoration of groundwater quality in ore bodies already leached by ammonia bicarbonate-carbonate solutions. Removal of all the ammonia absorbed to clay particles is considered to be neither economically practical nor technically feasible using current methods. Therefore, new methods are needed to remove the added ammonia or reduce the potential for its conversion to nitrates and nitrites which could adversely affect human health.

Excursion and restoration limits usually are set by using baseline water quality values; however, groundwater has natural variability that may not be accounted for in the baseline samples. Also geochemical changes may occur as the result of removal of the uranium and trace metals which would change the groundwater equilibrium. Thus, a need exists to determine restoration limits that reflect the potential variabilities in groundwater quality and potential geochemical changes that result from leaching. Consideration must be given to potential health and environmental effects resulting from constituents remaining after restoration. In order to determine the ability to remove a given lixiviant at a given site, pilot restoration demonstration is required as part of the plant license. Several people have pointed out that since the ore body has not been mined the geochemical changes cannot be fully predicted and these pilot restorations may not adequately represent the real restoration. Thus, there is a need for definition of methods for establishing restoration goals and restoration capacity that adequately protect the environment and represent the true restoration capabilities.

Among many regulators, a certain level of uncertainty exists regarding the nature and severity of environmental impacts of chemicals and procedures associated with the technology. This may lead to uncertainty with regard to the form that new standards or regulations should take, and to uncertainty regarding the most appropriate level for criteria and standards. As learning occurs, and as studies are conducted, criteria and requirements may change in response to the findings. Also as the technology changes, criteria may change. 
Among the industry, apprehension exists regarding constantly changing regulations or standards. Regulations often change too fast to allow sufficient rebuttal and are of ten not appropriate for certain forms of the technology. Keeping up with, or responding to, ever changing regulations, takes increasing amounts of industry staff time and resources.

Another complication of these uncertainties was noted at the November 1979 workshop. Growth of the industry may be impeded by the reluctance of companies new to the in situ uranium mining technology to initiate operations in the face of unknown future regulations. Workshop participants noted, for example, that regulators could conceivably make regulations so restrictive that compliance would be physically or economically impossible. While the uncertainty of the future regulations has not forced out companies already in production, the uncertainty has discouraged other interested companies from initiating operations.

Inflexible regulatory requirements allow regulators very little discretion in dealing with particular environmental and permitting problems associated with a particular facility. For example, in Wyoming, statutory language allows the Industrial Siting Administration only two decisions on construction either "go" or "no go." There is no conditional go ahead allowed, therefore, when a single part of a permit is incomplete, it could delay the entire project.

Many industrial representatives feel that permitting requirements are too rigid to allow the development of new variations on the technology because the regulations contain mandatory methods for doing things rather than allowing the operator the flexibility to choose the method to meet the intent of the regulations. The industrial representatives feel that the company must be able to continually adapt and refine the technology to achieve the best extraction and economics for a particular site. Regulators and public interest groups tend to be more conservative and are concerned that the new technological advances may have adverse environmental impacts that need to be regulated.

Industrial representatives have noted that regulators are not experts in the necessary fields and of ten do not fully understand the technology that they are regulating. Governmental and industrial representatives agreed that regulators must have adequate information and must be adequately educated about the technology before they can effectively regulate the industry. Basically, industrial representatives are concerned that regulations may be formulated from information gathered about other industries. There was a concern that, if the special needs of the industry were not considered, regulations could be promulgated that would prevent expansion into new geographical areas and impede responsible industrial growth.

The possibility of this worst case happening may be remote. Regulations in Texas have become less restrictive and more flexible in recent years. Also, the USNRC has been licensing in situ facilities for several years and bases all licenses on the most current information available and on past regulatory 
experience (state and Federal) with the in situ industry. State agency requirements in Wyoming are in some cases more restrictive than the USNRC requirements.

Additional problems have arisen from outdated information: the industry has problems that the regulators may not yet understand. Because companies are focussing on getting plants on-line and have needed to keep industrial processes secret, they have not spent time educating the regulators. Education of regulators and communication with the public were considered by some workshop participants to be especially desirable with the hopes that reasonable regulations may be issued and drastic changes or "tighter is necessarily better" attitudes may be forestalled.

Based on discussion concerning the extent to which these problems (i11 informed, not adequately educated regulators) occur, the participants felt that these problems are further exacerbated by high regulatory staff turnover, reducing opportunities to become knowledgeable in the field. Regulators having become educated in the technology usually leave or are transferred to a new assignment. Part of the problem is caused by agency structure that results in frequent reorganization and reassignment of personnel. Another contributing factor is the salary differential between state and Federal agencies and industry.

Regulatory problems and the reactions of environmental groups are due, at least in part, to inadequate or outdated information. First, the technology is undergoing and probably will continue to undergo, rapid and frequent changes, making constant exchange of information on state-of-the-art technology necessary. Second, in situ uranium mining is a relatively unknown technology outside the states of Texas and Wyoming where it is applied commercially. Most of the development of in situ facilities has occurred in Texas and, therefore, most of the information on environmental impacts has been accumulated in that state. Due to the agreement state status of Texas, much of the inf ormation gathered by industry, regulators, and environmental ists is not readily available to the Federal government or to groups or agencies outside Texas. In addition, the information has been gathered for Texas and may not be totally applicable to other states. Many of the participants at the November 1979 workshop recognized the need for increased exchanges of experiences and information, perhaps in workshops and conferences.

When a company or in situ operation is found to be violating a permit requirement or causing a measurable environmental impact that the regulatory agency is unaware of, the reaction of the regulatory agencies of ten is to increase regulations or delay permits. These changes or delays have numerous ramifications on all the companies in the industry. Recently, emphasis has been placed on punishing offenders and not punishing the entire industry. 


\section{FINDINGS AND RECOMMENDATIONS}

Based on the analysis of the available information, significant negative environmental impacts do not appear to result from development and deployment of in situ uranium mining technology. Areas that are unknown or where inadequate information is available include radon emission and effectiveness of groundwater restoration techniques, including the removal of nitrates and nitrites. Research is ongoing in these areas to answer questions about environmental impact and to develop effective and environmentally safe methods for restoration. Issues impeding development and/or deployment of in situ uranium mining technology are primarily related to interactions between government regulators and industrial representatives. Some of the major issues include inadequate communication, uncertainties about criteria and requirements and definition of acceptable restoration goals. Little has been done to try to overcome these impediments.

It is, therefore, recommended that the research into methods to address the major environmental health and safety issues be encouraged and continued. It is also recommended that activities be developed for more effectively dealing with the institutional impediments and for encouraging clearer and more frequent communications between regulators and industry representatives. 
OFFSITE

A. A. Churm

DOE Chicago Patent Group 9800 S. Cass Avenue

27 DoE Technical Information Center

\begin{tabular}{|c|}
\hline $\begin{array}{l}\text { Wenerman, Administr } \\
\text { Wyaming OEQ } \\
\text { Land Quality Dotvision } \\
\text { Hathawsy Building } \\
\text { Cheyenne, Wo } 82002\end{array}$ \\
\hline $\begin{array}{l}\text { R. Allem } \\
\text { G.C.O. Minerals Company } \\
\text { Po. Sox } 4258 \\
\text { Houston, } T x \quad 77210\end{array}$ \\
\hline
\end{tabular}

L. F. Anderson

Utan State Division of Hedith

Bur. of Radiation \&

occupational Heal th

Sait Lake Cfty, UT 1110

c. Barteis

Un ion Carbide

genavides, TX 78341

W. 5. Bartholome

Water Resources Department

State of oregon
55513 th 5 treet N.E.
Salem, oR 97310

P. Bis nop

Sunoco Energy Dev. Company

12700 Park Centra i

Box 9, Suite 1500

M. Brom

Colorado Department of Health

4210 E. II th Avernu

M. Buck ley

Mobil ofl Corporation

Corpus Chr isti, Tx 78403

R. L. Bulloxi
Exxon Minerats Co., U.S.A.

.0. Box 2180

Hou ston, TX 77001

G. Cressue 11

Uran ium Superviso

mobil oil corp.

Denver, $C 0 \quad 30220$

G. R. Davis, Manager

Anaconda Copoet Co.
Sauth Tex as uran ium Project

Solth Texas Uran ium Project
1400 Bank \& Trust Tomer

Corpus, Christi, TX 78477

L. Deve 1

Texas A \& Mn iversity

Dept. of Soll Crop Sciences

College station, $T X$ 77843

R. J. Everett

Nuc lear Regulatory Commission

Region IV, off tce of

inspections Enforcement 611 Ryan Plaza Drive, Sutte 1000

W. G. Fellioms

Arizona Atomic Energy Commission 2929 Hest Ind inn school Road

Phoen ix, AR 85017

K. B. Fess

Radtologic Health Section

State Department of Health

714 S Street

Sacramento, CA 95814
V. Franc is

Texas Dept. of Water Resources

Dellerest Plaza 12 Builuing

4713 Rigsby Avenue
San Antonio, TX 78222

R. Ganewe 11

Radi at ion 4 Hazardous Waste Control Division Colorado Dept. of Health 4210 E. 11 th Ave.

W. Gatland, Aanin istrator Wyowing DEO

Water Qual ity Division

Hath away Building
Cheyerne, iv 82002

P. Griastad

Department of Ecology

Sou thiest Regional off $i c$

.s. Lu-11

7272 Cleanwater Lan

H. H. Harr is

Surf ace Mine Land Management

Spec $i$ al ist

Divis ion of Conservation

Departitent of Agriculture

Anderson Building,
Pierte, SD 57501

8. M. Hartley

Dept. of Public Health

Merdical Services

Westerm Australi an Govermment

Verdun Street

H. AUSTRAi IA 6009

C. Henry

Texas Bureau of Economic Geology

University of Texis

University Station, $80 x-x$

Aust in, $T X 78712$

8. Hill

The Anaconda Compony

1400 Bank and Trust Touer

D. $\mathrm{Hill}$

Maration $0 i$

Littleton, CO 80160

8. Howard

Bureau of Radiation ?

occupational Heal th

P.0. Box 2500

Salt Lake City, is 84110

5. J. Hubbard

Extraction Technology Branch

U.S. Eny. Protection Agency

M. Hulburt

Dept. of Enviromental Quality

Land quality Division

Hath away Bufl lding

Humenick

Un ivers ity of Texas

Callege of Engineering

Department of Civil Engineering

E. Johnson

Radiological Health Services

Dept of Health 3 Social Services

state off $1 \mathrm{ce} B \mathrm{l} \mathrm{dg}$. . Hest

V. Kallemeyn.

Dept. Of Enviror

Joe Foss building
P. Kutchinsty

Texas Dept. of Water Resources

District 12

Corpus Christi, IX 78401

F. C. Lenzo

Dept. of Conservation

Envirolent

Perth.

H. Austan. IA 6000

R. E. Lewis

Texss Dept. of Water Resources District 12

Corpus Christ1, TX 78401

L. L. Lloyd

Radiological \& Occupational

Heslth Progra

Dept. Of Health \& Env. Sciences

Cogsuell Building
Heiend, at 59601

A. Luck

Conoco Ine.

Minerals Department

555 Severteenth St.

555 sever teen th $5 t$.

J. Mack in

Env. Improvement Division

Radiation Protection Section

P.O. Box 968

Crom Building 87503

$\checkmark$. Mathis

UREX 212 Gaslight Square

212 Gaslight Square 7840

H. O. May

U.S. Environpenta 1 Protection Agency
Ffrst intemational Buliding

1201 E in Street

H. McCoy

Texas Dept. of Water Resources

813 East Pike 81 ivd

C. R. Meirtsenin

Texas Dept, of Water Resources

Texas Dept, of

Cesitol station

Aust in, TX 7871.

6. Hiller

.0. Box 22

Denver, $c 0$ 80201

K. Mash

U. S. Envitronmental Protection

Agency

Rallas, TX 75221

T. Paimer

Texas Air Control Board
8520 Shool Creek Blyd.

Aust in. TX 78758

M. Peltiza

P.0. Bor 528

Benavides, TX 7834

P. Roberts

Texas Air Conrol Board

8520 Shod Creek B Ivd.
Aust in, TX 78758

R. Roentich

Arizona Atogic Energy Comission 2929 West ind an S=hol Road Phoenix, AR 85017
E. Rothschild

Intercontinental Energy

Corporation

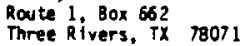

C. Rut ledge, Jr.

yrowing Hineral Corporation

lakebod, 0080235

R. Ryan

Hyaning Mineral Corporation

3900 South Wadsworth 81 ivd.

M. Schurtz

University of Texas

College of Engineering

Departaent of Civil Engineerting

Nust in, TX 78712

F. C. Sherman

Hontand Oept. of Health

Enviromental seiences

Water Quality Bureau

Helena, uT 59601

G. Stemert

Env. Improvement Division

Radiation Protection Section

P.0. $80 x 968$

Santa Fe, NM 87503

D. A. Stemart-Saith

State Health Oivision

P.0. Box 231

Portland, on 97207

B. Storbeck

University of Texas

College of Engineering

Department of CIvil Engineering

B. Taylor

Exxon Minerals Co., U.S.A.

Houston, $\mathrm{TX}_{\mathrm{X}} 7 \mathrm{O}$

E. H. Tiepel

yyoming Mineral Corporation

Soo South Wadsworth Bivd.

8. Trippet

Moo11 011 Corporation P.0. Box 2588

Corpus Christi, TX 78403

H. H. Trussell, Jr.

Exxon Minerals Co., U.S.A.

P.0. Box 2180

Howston, ix 77001

H. Tuchteld

Moodward - Clyde Consul tants

Emoarcadero Center, Suite 700

R. Will

Radiation Contol Progras

Department of Social 6

Heal th Services

Mail Stop LD-11

D. Whittington

University of Texas

College of Engineering

Dept. of Civil Engineering

ONSITE

W Bair

CE Coman (18)

OL Hessel (5)

Publ ishing Coordination (2)

Technical Information (5) 